\title{
New Record of Long-Eared Hedgehog, Hemiechinus Auritus (Gmelin, 1770) in Sohag Governorate, Egypt
}

\author{
Abd El-Aleem Saad Soliman Desoky* \\ Plant protection Department (Agricultural Zoology), Egypt
}

*Corresponding author: Abd El-Aleem Saad Soliman Desoky, Plant protection Department (Agricultural Zoology), Faculty

Agriculture, Egypt

\begin{tabular}{|c|c|}
\hline ARTICLE INFO & ABSTRACT \\
\hline Received: 慧 June 12, 2019 & The study aims to identify new types of rodents or small mammals in Sohag \\
\hline Published: 幽 June 21, 2019 & $\begin{array}{l}\text { Governorate. This study showed the new record of long-eared hedgehog, Hemiechinus } \\
\text { auritus in the Village of Awlad Nasir-Naga Tarkhan, north of Sohag Governorate. It's the }\end{array}$ \\
\hline
\end{tabular}

Citation: Abd El-Aleem Saad Soliman Desoky. New Record of Long-Eared Hedgehog, Hemiechinus Auritus (Gmelin, 1770) in Sohag Governorate, Egypt. Biomed J Sci \& Tech Res 19(1)-2019. BJSTR. MS.ID.003239.

\section{Introduction}

Hemiechinus collaris is a burrowing and nocturnal species, recorded near water and agricultural landscapes Roberts [1] \& Molur et al. [2] This species is useful indirectly to human being as it consumes insects, termites and scorpions. While H. collaris does not damage agriculture and lives on the edge of agriculture land or near desert and this species has no conflict with human. Long-eared hedgehog avoid high heat; strictly nocturnal in summer, emerging at dusk and feed for 5 to 6 hours Roberts [1]. They excavate their burrows; burrow entrance is covered under bushes and shrub; when ground is hard it may be less than one than one foot. In sandy and softer soil, the burrow may be more than 5 feet. The burrow leads to wider chamber, inside a small chamber Krishna and Parakash [3]. The burrow has sloped about one foot below the surface. H. collaris is unsocial species and does not share a burrow with the same species Roberts [1]. This species food is insects, insect larvae, lizards, birds' eggs, cannibalism is also recorded in this species; female eat their own offspring; while adult eat their young hedgehog Prakash [4]. This species also attacked on the dangerous prey (i.e. venomous snakes) and eat them Krishna and Parakash [3] \& Mirza [5]. Hemiechimus auritus is distributed in Libya, Egypt, Iraq, Israel, Lebanon, Syria, Turkey, USSR, Iran, India, Afghanistan, Pakistan, Mongolia, China. Colak et al. [6].

\section{Materials and Methods}

During the identification of rodents in Sohag Governorate, we noticed the presence of a hedgehog in Sohag District at the Village of Awlad Nasir - Naja Tarkhan at the north of the Sohag District about $2 \mathrm{~km}$. Samples were collected for breeding in the laboratory and identification. Identification of the hedgehog were done using different keys constructed by Anderson [7], Flower [8], Wassif [9], Setzer [10] and Osborn \& Helmy [11, 12].

\section{Results and Discussion}

These animals were observed in the Village of Awlad Nasir - Naga Tarkhan, north of Sohag Governorate, at the period from afternoon to the sunset. Especially after the sunset because it's activity at night. These animals appeared after the harvest period of the wheat crop in burrows under the piles of corn, sorghum \& palm trees and on the sides of the agricultural canals, feeding on soil insects, grass and some pests. we transferred them to the agricultural animal laboratory for breeding and classified according to the different keys of the taxonomy in the animal kingdom as follows: (Figure 1). 


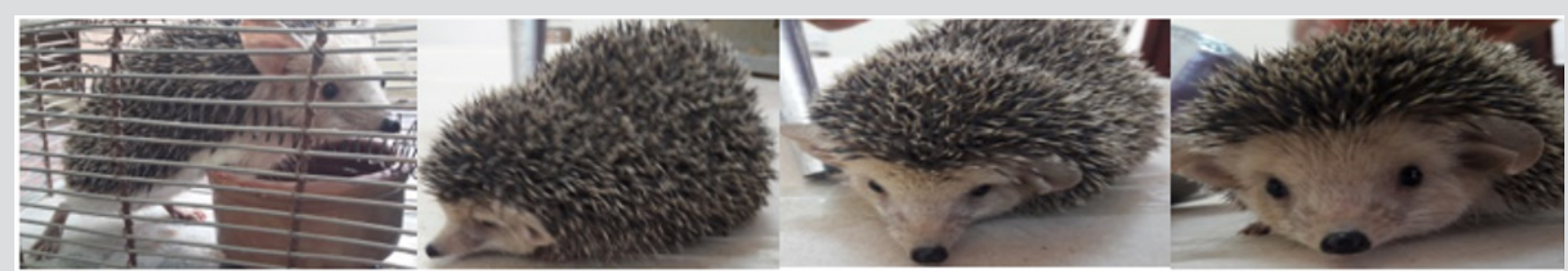

Kingdom: Animalia

Phylum: Chordata

Class: Mammalia

Order: Erinaceomorpha (Insectivora)

Family: Erinaceidae

Genus: Hemiechinus

Species: Hemiechinus auritus

Common name: Long-eared hedgehog

Figure 1: Long-eared hedgehog (Hemiechinus auritus).

The results similar with Anderson [7], Flower [8], Wassif [9], Setzer [10] and Osborn \& Helmy [11,12]. The long-eared hedgehog, Hemiechinus auritus was collected from Kawm El-Aaqula area, 15 $\mathrm{km}$ west of El-Burg. Two specimens were caught alive from their burrow under the vegetation, collected this hedgehog from Baltim and El-Burg. The sub specific status of this hedgehog is aegyptius. By the analysis of stomach contents, insects formed the only food item. So, it is recorded before, in the Nile Delta, but This research is the first record of long-eared hedgehog from to the south in Sohag Governorate (Upper Egypt). We suggest that more work and surveys should be done to know the distribution of all mammalian species in the region and their impact on the environment, whether useful or harmful.

\section{References}

1. Roberts TJ (1997) The Mammals of Pakistan. Oxford University Press. New York, USA.

2. Molur S, C Srinivasulu, B Srinivasulu, S Walker, PO Nameer, et al. (2005) Status of nonvolant small mammals Conservation Assessment and Management Plan (C.A.M.P) Zoo Outreach Organisation / CBSG-South Asia, Coimbatore, India.

3. Krishna D, I Parakash (1955) Hedgehog of the desert of Rajasthan. JBNHS 53: 362-366.

\section{ISSN: 2574-1241}

DOI: 10.26717/BJSTR.2019.19.003239

Abd El-Aleem Saad Soliman Desoky. Biomed J Sci \& Tech Res

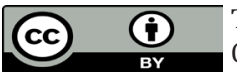

This work is licensed under Creative Commons Attribution 4.0 License

Submission Link: https://biomedres.us/submit-manuscript.php
4. Prakash I (1955) Cannibalism in Hegdgehogs. JBNHS 52: 100-109.

5. Mirza ZB (1969) The Small mammals of West Pakistan. Central Urdu Board. Lahore, Pakistan.

6. Çolak E, N Yigit, M Sozen, S Özkurt (1998) A Study on the Long-eared hedgehog, Hemiechinus auritus (Gmelin, 1770) (Mammalia: Insectivora) in Turkey, Tr J of Zoology 22: 131-136.

7. Anderson J (1902) Zoology of Egypt. Mammalia (revised and completed by WE De Winton). Hugh Ress Ltd London.

8. Flower S (1932) Notes on the recent mammals of Egypt, with a list of the species recorded from that Kingdom. Proc Zool Soc London 102(2): 368-450.

9. Wassif K (1995) Guide to Mammals of Natural Protectorates in Egypt. National Biodivesity Unit. No. 4, Egypt. Envir. Aff. Agency (EEAA), Cairo, p. 85 .

10. Setzer H (1957) The hedgehogs and shrews (Insectivora) of Egypt. J Egypt Publ Hlth Ass 32: 1-17.

11. Osborn D, Helmy I (1980) The contemporary land mammals of Egypt (including Sinai). Fieldiana Zool New Series No. 5.

12. Species Composition. Mammals Chapter 13.

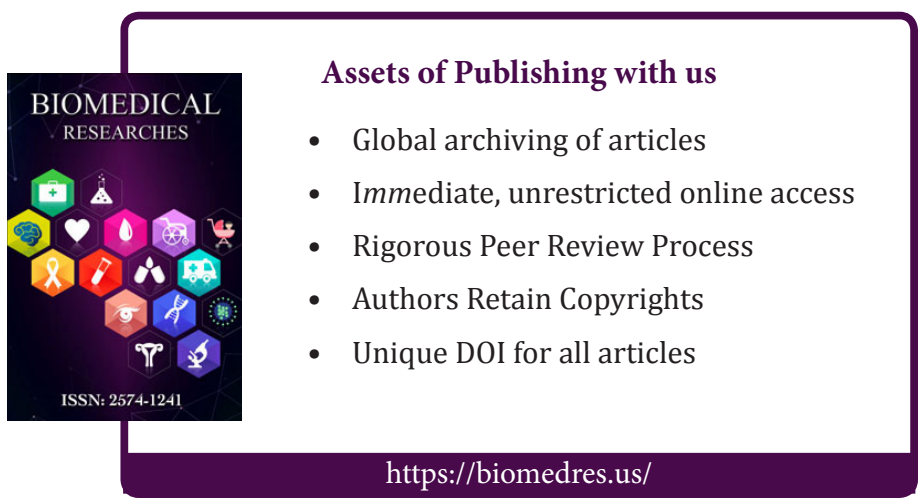

Copyright@ Abd El-Aleem Saad Soliman Desoky | Biomed J Sci \& Tech Res| BJSTR. MS.ID.003239. 